\title{
血管損傷修復とマスト細胞キマーゼ
}

\section{奥西秀樹 ・塩田直孝・高井真司・宮㟝瑞夫*}

Role of mast cell chymase in excessive woundhealing response to vascular injury

This study has analyzed the pathogenetic mechanism of the intimal thickening after baloon injury, which is currently a serious problem on the balloon angioplasty for coronary arteriosclerosis, from the aspect of wound-healing inflammation. The locally generated angiotensin II (A II), which is known for its aggravating effect on vascular hypertrophy, has been implicated to participate in the pathogenic mechanism. One month after the balloon injury, dog arteries showed myointimal hyperplasia as well as the increases in A II and A II-generating enzymes, angiotensin-converting enzyme and mast cell chymase, with the latter enzyme increasing more markedly. In the adventitia of lesioned vessels, the density of mast cells and fibrolasts was increased with apparent fibrosis and angiogenesis. These pathohistological findings suggest that the adventitial fibrosis reflects an excessive woundhealing response to the injury, and that the mast cell-fibroblast cross-talk may couple the adventitial fibrosis with the intimal hyperplasia. In this hyperplastic lesion, mast cell chymase seems to play a pivotal role by generating A II, and also by chymase's proinflammatory actions which are not yet fully defined. Thus, it is reasonable to regard the intimal thickening as a manifestation of exaggerated wound-healing response to an injury.

Hideki Okunishi • Naotaka Shiota •

Shinji Takai $\cdot$ Mizuo Miyazaki*

key words : mast cell, chymase, wound healing, neointima, fibrosis

この小論では, 現在, 臨床的に大きな問題となっ ている経皮経管的冠動脈形成術(PTCA) 後の再狭 窄の発症機序を炎症学の視点から解析してみた い. 再狭窄は血管内膜の増殖・肥厚によるが，今 回の実験成績は，この内膜病変を“物理的傷害に 対する炎症性過剰修復反応1)”と見なすのが妥当

\footnotetext{
* Department of Pharmacology, Osaka Medical College
} 大阪医科大学薬理学教室
であることを示唆している.

動脈硬化に伴う冠動脈狭窄は本邦でも増加の一 途を辿っており, 心筋梗塞に至る重要な危険因子 である. 現在, 冠動脈狭窄の治療法としてバルー ンカテーテルによる内腔拡張術, 即ち PTCA が その簡便さのゆえに広く実施されている.しかし, PTCA で一次的拡張に成功しても, 半年以内に高 頻度で再狭窄を生じ，しかも，これを確実に防ぐ 手段はまだない2).

ラットのバルーン傷害血管に生じる反応性内膜 肥厚がアンジオテンシン変換酵素 $(\mathrm{ACE})$ 阻害薬 で予防できる ${ }^{3)} と$ こ, ヒト PTCA 後内膜肥厚 に対しても ACE 阻害薬の臨床試験が実施された が, 否定的な成績に終わった

一方, ACE の産生するアンジオテンシン II (A II) が細胞増殖, 肥大, 遊走作用や細胞外基質 (ECM) 産生立進作用を有することが知られてお り ${ }^{4)}$ ，ヒト血管でも AII は同様の作用を発揮するも のと推察される.

筆者らは, 従来, 血管組織における局所的な AII 産生機構を解析してきた ${ }^{5 \sim 7}$ 結果，ラット血管の AII 産生が ACE のみに依存するのとは異なり, ヒト血管ではキマーゼ (chymase)によるAII産生 が ACEよりも優位であることを見出した ${ }^{7)}$.この 血管 AII 産生機構における種差が ACE 阻害薬の 内膜肥厚予防効果の種差をもたらすのであろうと 仮定し，ヒト血管と同質のAII産生機構をもつイ 又血管 ${ }^{5,6)}$ においてバルーン傷害モデルを作成し, 病変発症機序の解明を試みた。その結果, キマー ゼの病変形成への関与が示唆されたばかりでな く，これまでまったく着目されていなかった傷害 部位の血管外膜炎症が内膜の炎症性肥厚と相関す ることを見出した。

\section{方 法}

ビーグル成犬の右側総頸動脈を小切開し, $3 \mathrm{~F}$ バ ルーンカテーテルを挿入して内腔面に傷害を加え 


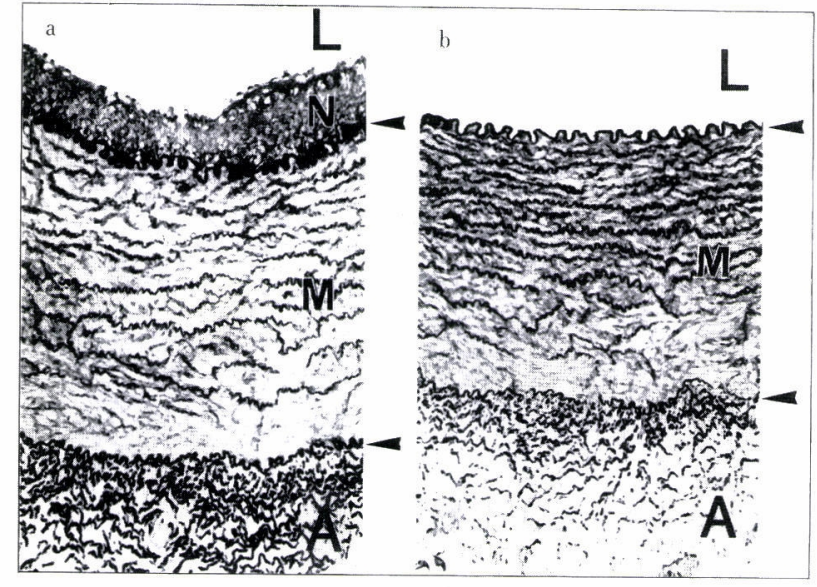

図 1 バルーン傷害による内膜肥厚

同一の個体から採取した傷害側(パネル A) と非傷 害・対照側(パネル B ) の弾性線維染色標本を示寸。 傷害側には典型的な新生内膜 $(\mathrm{N})$ を認めるが，対照 側には認められない。Lは血管内腔，Mは中膜，A は外膜を扝の扝の指示している。上方の矢は内弾性 板，下方の矢は外弾性板である。(文献 ${ }^{8)} よ り$ 改変)

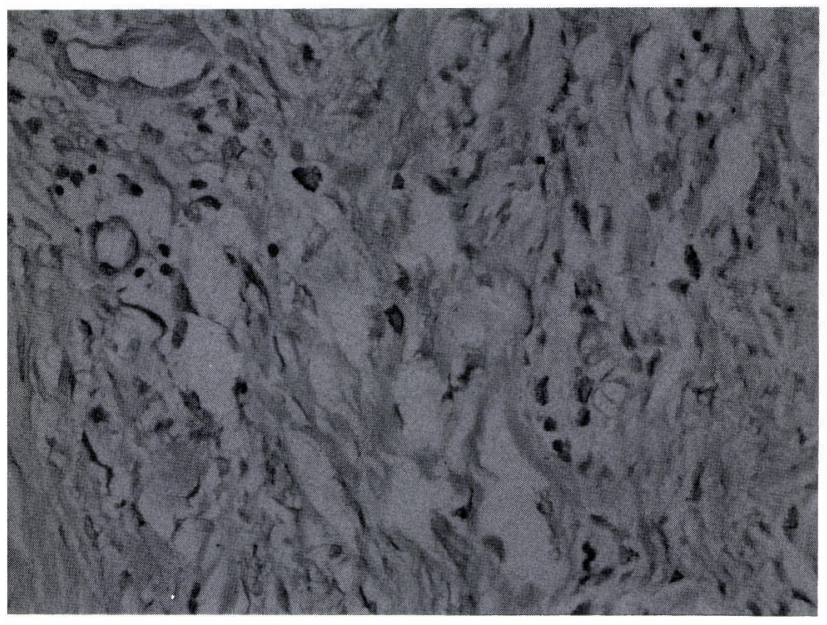

図 2 傷害側動脈外膜のトルイジンブルー染色 メタクロマジーを示すマスト細胞（矢頭）が多数出 現し, 線維芽細胞数の増加, コラーゲン線維の増生, および多数の血管新生 (矢印) が認められる。

た ${ }^{8)}$. 切開孔は極細ポリプロピレン系で, 狭窄しな いように注意を払って縫合閉鎖した。左側総頸動 脈は周囲組織から剝離するだけに留め, 対照とし た。術後 1 力月で両側頸動脈を摘出し, 以下の解 析を行った。

ホルマリン固定後, (1) ヘマトキシリン・エオジ ン染色標本を病理組織学的に解析し, (2) 弾性線維
染色標本の画像解析により, 内膜肥厚を定量化し, (3) トルイジンブルー染色でメタクロマジーを示 すマスト細胞を計数した。

AII 産生系の動態を示す指標として，ACE およ びキマーゼの酵素活性(6)なびに mRNA レベル (おのおのの cDNA に特異的なプライマーを合成

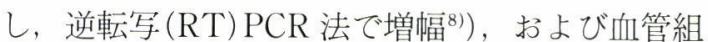
織AII濃度(固相抽出物を逆相 HPLCで分画した あと,ラジオイムノアッセイで定量)を測定した。

\section{結 果}

傷害側動脈は内腔狭窄を呈し，これは平滑筋細 胞の内膜への遊走と, 内膜での増殖, ECM 増生を 伴う新生内膜(Neointima)によるものであった (図 1 ). 新生内膜は内弾性板の断裂部に一致して もつとも顕著であった。内膜肥厚部に相当する血 管外膜では，マスト細胞および線維芽細胞が増加 し，コラーゲンと思われる ECM 増生や血管新生 が多数認められた(図 2 ).

傷害側動脈では，対照側に比して，ACE 活性が 4.6 倍に，ACEmRNA は4.8倍にそれぞれ上昇 し，キマーゼ活性は 22 倍に，キマーゼ mRNA は 3.4 倍に上昇していた(図 3 )。血管組織AII 濃度 は対照側の約 2 倍に増加していた(図 4)。

\section{考 察}

バルーンカテーテルによる物理的傷害が血管壁 に加わると，それに反応してキマーゼと ACE は いずれも遺伝子発現が増加し，酵素活性が上昇し た。これらの酵素により局所的な AII 産生が増加 し, AIIの増殖因子様作用 ${ }^{4)}$ の結果として平滑筋の 内膜への遊走，内膜での増殖・ECM 増生が引き起 こされたものと考えられる(図 5 )。

$\mathrm{ACE} よ り も キ マ ー セ ゙ の$ 活性増加が顕著である ことから, キマーゼによる AII 産生が病変形成の 主役であると推察されるが，この推察の妥当性は 別に得られた実験成績—AII 受容体拮抗薬は内 膜肥厚を抑制したが, ACE 阻害薬の効果は軽微で あった(奥西ら，第 16 回日本高血圧学会，1993) 一により支持される.

二つの阻害薬の効果がいちじるしく異なるの は，AII拮抗薬がAII産生経路に拘らずAIIの作用 を受容体レベルで遮断する9のに対し，ACE 阻害 


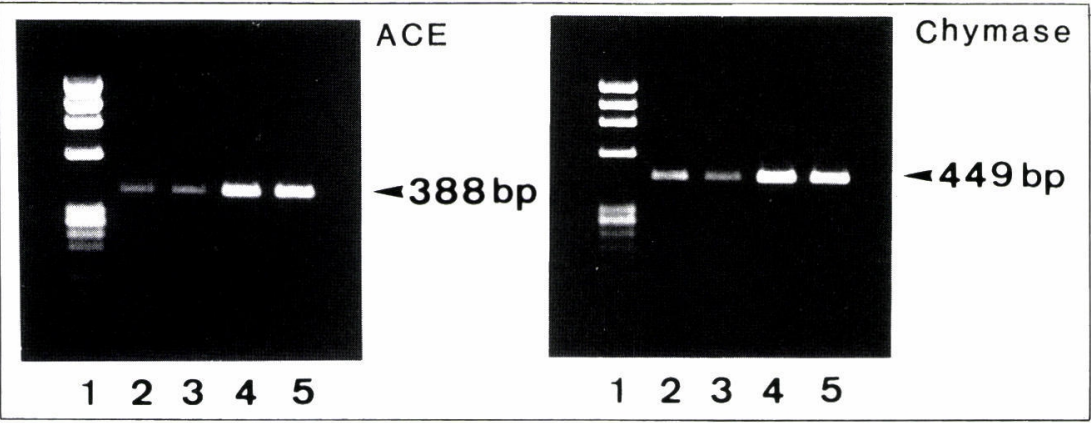

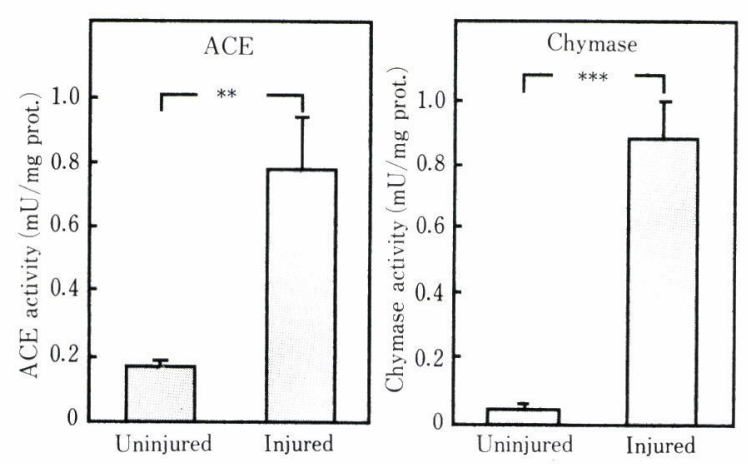

図 3 傷害によるアンジオテンシンII産生酵素の活 性および遺伝子発現の変化

上段パネルは RT-PCR 法による ACE とキマーゼ の mRNA レベルを示す.レーン1はマーカー, レー ン 2 と 3 は対照側, レーン 4 と 5 は傷害側を示す。 傷害側では ACE, キマーゼともに遺伝子発現レベル が上昇している。

下段パネルは ACE およびキマーゼの活性 (6 例の 平均値土標準誤差)を示す、いずれの酵素活性も傷害 側で増加している.

薬はキマーゼを阻害せずAII の産生を遮断できな い5 7)からである，と解釈できる。

傷害部の外膜に打いてマスト細胞や線維芽細胞 が増加したのは，たんに血管を周囲結合織から剥 離したからではない。 なぜなら，同様に周囲組織 を剥離した対照側血管では内膜肥厚も外膜炎症も 生じないからである。

キマーゼはマスト細胞由来のプロテアーゼであ $\eta^{10,11)}$, 傷害部位においてキマーゼ活性が増加し ている生化学的所見は, 同部位の外膜に拀いてマ スト細胞が増加している病理組織学的所見と符合 する。マスト細胞が線維芽細胞とともにケロイド や線維化などの慢性肉芽性炎症に何らかの寄与を していることは早くから指摘されてきたが12,13), 分子レベルでの詳細な解析はまだ不十分である。

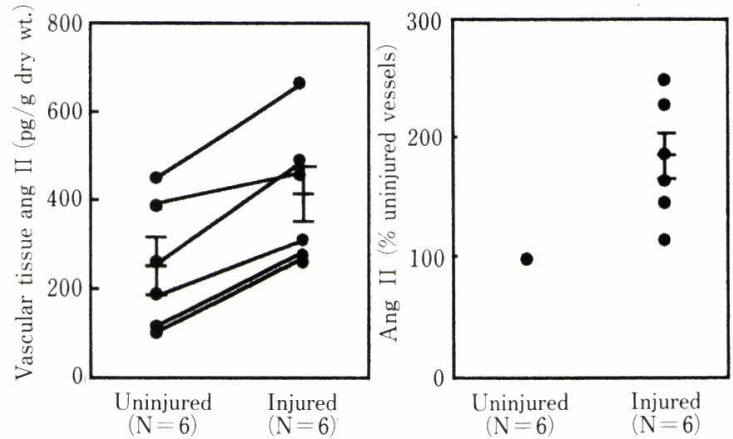

図 4 血管組織中のアンジオテンシンII濃度 左パネルはAII 濃度(組織乾燥重量あたりの AII 量) の実測值を示す。右パネルは各個体ごとの対照側の 数值を基準として標準化したもの。すべての個体で 傷害側の AII 濃度が上昇している。3 本の短い横線 は平均値士標準詋差をあらわす。

同様に，慢性炎症におけるキマーゼの役割も実証 されていない，損傷修復部位におけるキマーゼ活 性の上昇を示す今回の実験成績と, AII拮抗薬の 内膜肥厚予防効果 (既述)とを考え併せると，血管 キマーゼの炎症性過剩修復反応における役割が, 間接的にではあるが，示されたといってよい，直 接の証明には特異的なキマーゼ阻害薬の開発を待 たねばならない。

今回の結果は, キマーゼがAII産生を介して損 傷修復性炎症又応に関与していることを示した が，キマーゼの炎症に打ける役割はこれに留まら ないと, 筆者らは考えている。なぜなら, キマー ゼはフィブロネクチン・14やコラーゲン10)などの ECM, IL-1 $\beta^{15)} や \mathrm{IL}-4$ (M. K. Church 私信) など のサイトカイン, $\operatorname{IgG}$ および血液凝固因子などを 限定分解し ${ }^{10)}$, これらの蛋白分子を修飾すること が知られており，この機能を通じて組織修復性炎 症反応に深く関わっていると考えられるからであ る。これらの諸相を特異的キマーゼ阻害薬の開発 


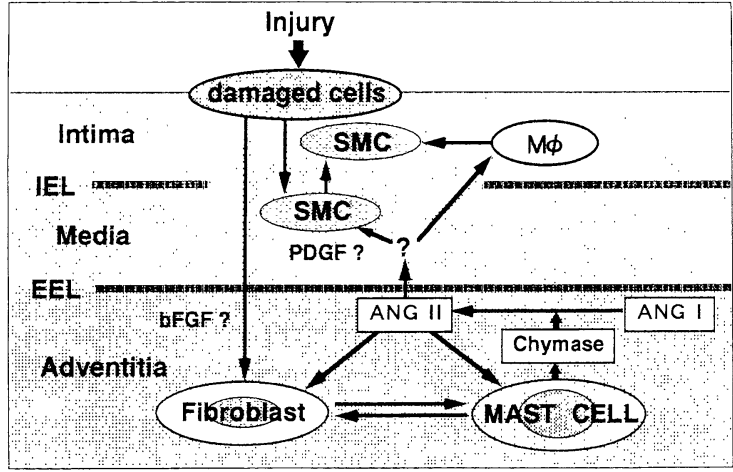

図 5 バルーン傷害による内膜損傷や内弾性板断裂 が新生内膜肥厚および外膜の線維性炎症を起 こす機序 (仮説)

血管内膜に傷害が加わると，損傷細胞から bFGF な どの成長因子が放出される。 bFGF は平滑筋細胞 (SMC) を内膜へ遊走させたり，外膜の線維芽細胞を 活性化し, それによってマスト細胞が活性化される. マスト細胞はキマーゼを放出し，アンジオテンシン I をIIに変換する。アンジオテンシンIIはオートク リン・パラクリン的にマスト細胞自身や線維芽細胞 に作用して外膜の増殖性炎症を促進し, 平滑筋細胞 やマクロファージ $(\mathrm{M} \phi)$ に直接，あるいは間接 (PDGF 等を介して)に作用して内膜肥厚を促進す る. IEL：内弾性板. EEL：外弾性板

\section{により解明していきたい.}

今回のデータでは, キマーゼ活性の増加率と遺 伝子発現の増加率との間に乘離がみられたが，こ れはキマーゼがマスト細胞から持続して緩徐に放 出されたあと, マスト細胞表面や ECM プロテオ グリカンに結合して安定な形で(言わば固定化酵 素として)存在する ${ }^{11}$ からであろう。つまり，キ マーゼ遺伝子発現やマスト細胞脱顆粒がわずかに 克進しただけでも，細胞外スペースでは大きなキ マーゼ活性増加を招来すると考えられる。

内膜に対する傷害がいかにして外膜のマスト細 胞および線維芽細胞を活性化するかは未解決の問 題であるが，図 5 に示すように，抢そらく傷害さ れた内皮細胞や一部の平滑筋細胞から放出された bFGF などが外膜の線維芽細胞を活性化し ${ }^{16)}$ ，線 維芽細胞は SCF (c-kit ligand ともよばれる)を分 泌してマスト細胞前駆細胞の分化・増殖をもたら す17)ものと推察している.さらに, c-kit 受容体が 活性化されたマスト細胞はキマーゼの遺伝子発現 および細胞外放出を促進して AII 産生を高めるほ

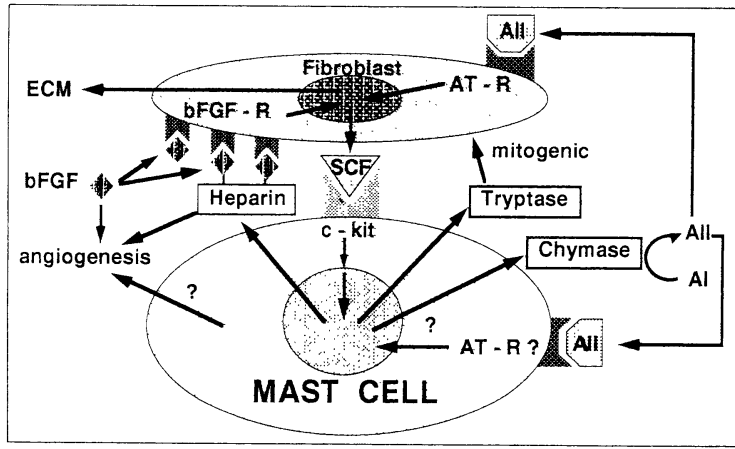

図 6 血管外膜におけるマスト細胞と線維芽細胞の クロストーク

損傷細胞から放出された bFGF は線維芽細胞を活 性化し SCF (c-kit ligand)を分泌させる. SCF はマ ス卜細胞の分化・増殖を誘発するとともに多様な炎 症促進物質を放出させ、これら物質はさらに線維芽 細胞の増殖と活性化を誘発して細胞外マトリックス $(\mathrm{ECM})$ 増生や血管新生を促進する。これが今回の病 理組織像に反映されていると考えられる.

AT-R：アンジオテンシン II 受容体. bFGF-R : bFGF 受容体

か，へパリン，ヒスタミン， $\mathrm{IL}-4, \mathrm{TNF}-\alpha$, トリ プターゼなど多種多様な炎症修飾物質を放出して 線維芽細胞の増殖や ECM 増生 ${ }^{17,18)}$ ，血管新生 ${ }^{19)}$ を引き起こすと考えられる。

外膜におけけるマス卜細胞と線維芽細胞とのク ロストーク (図 6 ) は, 外膜の線維化(炎症性組織修 復)を起こすだけでなく, 新生内膜形成の駆動力と もなっているに違いない ${ }^{16)}$ 。この考えを指示する 事実として，マスト細胞や線維芽細胞の機能を抑 制するトラニラストがケロイド形成を抑制した $\eta^{20)}$ ，ヒト PTCA 後再狭窄を予防すること(上田 ら, 第 40 回日本心臓病学会, 1992)があげられる.

これらの事実を総合すると，キマーゼはたんに 物理的傷害に対する亜急性修復反応に関わるだけ でなく，さらに広範囲の免疫性・非免疫性の慢性 肥厚性血管炎(多くは原因不明の難病である)にも 深く関わっている可能性が強い.

\section{結 論}

この研究は傷害血管の内膜肥厚に血管キマーゼ が重要な役割を果たしていること，内膜肥厚はた んに内膜だけの炎症反応ではなく外膜の過剰修復 炎症と呼応していること，を明らかにした。 
AII の定量法は金勝慶博士 (大阪市大) に，マス 卜細胞の染色・同定は山本隆一博士 (大阪医大) お よび有薗直樹博士 (京都府立医大) に, 分子生物学 的技術は深水昭吉, 村上和雄両博士(筑波大) およ び中川俊正博士 (大阪医大)にそれぞれ負うところ が大であったことを記して深謝します。

\section{文 献}

1) Forrester, J.S., Fishbein, M., Helfant, R., Fagin, J. : A paradigm for restenosis based on cell biology : clues for the development of new preventive therapies. J. Am. Coll. Cardiol. 17 : 758-769, 1991.

2) Heyndrickx, G. R., the MERCATOR study group : Angiotensin-converting enzyme inhibitor in a human model of restenosis. Angiotensin and the heart. (ed. Grobecker, H., Heusch, G., Strauer, B. E.), Steinkopff Verlag, Darmstadt, 1993, p 169-182.

3) Powell, J. S., Clozel, J.-P., Muller, R. K. M., Kuhn, H., Hefti, F., Hosang, M., Baumgartner, H. R. : Inhibitors of angiotensin-converting enzyme prevent myointimal proliferation after vascular injury. Science 245:186-188, 1989.

4) Schelling, P., Fischer, H., Ganten, D. : Angiotensin and cell growth : a link to cardiovascular hypertrophy? J. Hypertens. 9 : 3-15, 1991.

5) Okunishi, H., Miyazaki, M., Toda, N. : Evidence for a putatively new angiotensin II-generating enzyme in the vascular wall. J. Hypertens. $2: 277$ 284, 1984

6) Okunishi, H., Miyazaki, M., Okamura, T., Toda, N. : Different distribution of two types of angiotensin II-generating enzymes in the aortic wall. Biochem. Biophys. Res. Commun. 149 : 1186-1192, 1987.

7) Okunishi, H., Oka, Y., Shiota, N., Kawamoto, T., Song, K., Miyazaki, M. : Marked species-difference in the vascular angiotensin II-forming pathways: humans versus rodents. Japan. J. Pharmacol. $62:$ 207-210, 1993.

8) Shiota, N., Okunishi, H., Fukamizu, A., Sakonjo, H., Kikumori, M., Nishimura, T., Nakagawa, T., Murakami, K., Miyazaki, M. : Activation of two angiotensin-generating systems in the ballooninjured artery. FEBS Lett. 323 : 239-242, 1993.

9) Okunishi, H., Song, K., Oka, Y., Kobayashi, T.,
Kawamoto, T., Ishihara, H., Mori, N., Miyazaki, M. : In vitro pharmacology of a novel non-peptide angiotensin II-receptor antagonist, E4177. Japan. J. Pharmacol. 62 : 239-244, 1993.

10）木戸 博, 勝沼信彦：セリンプロテアーゼとアレルギ 一炎症の成立機序. 肥満細胞一生理と病理。(黒沢元博 編), メディカルレビュー社, 1990, p 167-179.

11) Sayama, S., Iozzo, R. V., Lazarus, G. S., Schechter, N. M. : Human skin chymotrypsin-like proteinase chymase. J. Biol. Chem. $262: 6808-6815,1987$.

12) Enerback, L., Norrby, K. : The mast cells. Cell kinetics of the inflammatory reaction. Curr. Topics Pathol. 79. (ed. Iversen, O. H.), Springer, New York, 1989, p 169-204.

13) Galli, S. J. : New concepts about the mast cell. New Engl. J. Med. $328:$ 257-265, 1993.

14) Vartio, T., Seppa, H., Vaheri, A. : Susceptibility of soluble and matrix fibronectins to degradation by tissue proteinases, mast cell chymase and cathepsin G. J. Biol. Chem. 256 : 471-477, 1981.

15) Mizutani, H., Schechter N., Lazarus, G., Black, R. A., Kupper, T. S. : Rapid and specific conversion of precursor interleukin $1 \beta$ to an active IL-1 species by human mast cell chymase. J. Exp. Med. 174 : 821-825, 1991.

16) Edelman, E. R., Nugent, M. A., Smith, L. T., Karnovsky, M. J. : Basic fibroblast growth factor enhances the coupling of intimal hyperplasia and proliferation of vasa vasorum in injured rat arteries. J. Clin. Invest. $89: 465-473,1992$.

17) Galli, S. J., Tsai, M., Wershil, B. K. : The $c^{-k i t}$ receptor, stem cell factor, and mast cells. Am. J. Pathol. 142 : 965-974, 1993.

18) Metcalfe, D. D., Costa, J. J., Burd, P. R. : Mast cells and basophils. Inflammation : basic principles and clinical correlates. 2nd ed. (ed. Gallin, J. I., Goldstein, I. M., Snyderman, R.), Raven Press, New York, 1992, p 709-725.

19) Klagsbrun, M. : Mediators of angiogenesis: the biological significance of basic fibroblast growth factor(bFGF)-heparin and heparan sulfate interactions. Cancer Biol. $3:$ 81-87, 1992.

20) Suzawa, H., Kikuchi, S., Arai, N., Koda, A. : The mechanism involved in the inhibitory action of tranilast on collagen biosynthesis of keloid fibroblasts. Japan. J. Pharmacol. 60 : 91-96, 1992. 